\title{
Upaya Pencegahan Sexual Violence Pada Remaja Sekolah di Merawang Kabupaten Bangka
}

\author{
Sujadmi ${ }^{1}$, Luna Febriani ${ }^{2}$, Herdiyanti $^{3}$ \\ ${ }^{1,2,3}$ Lecturer in the Departement of Sociology University of Bangka Belitung \\ Sujad.m13@gmail.com,lunafebriani.lf@gmail.com,vhie_dyan@yahoo.co.id
}

\begin{abstract}
The right for good life such as education and peace are one of them. They often experience sexual violence and abuse. The case of sexual abuse faced by them increases. This requires special attention to solve and prevent the case. The perpetrators mostly are adults and even from the member of family. The educators are expected to be the role model for the pupils not otherwise. To tackle the issue, it requires the knowledge and a strategy to prevent the mentioned case. Sex education can be one of the solutions to prevent the mentioned case experienced by the children and teenage girl so that they are able to identify the types of sexual violence. Extension can be conducted as the form of education. It can be through providing the flyers and stickers to teenagers and to the other people. High school becomes its target. The extension was conducted in SMAN 1 Merawang. The keynote speaker of the events were the expert from educational and psychological field. It was expected by having enough knowledge on types of sexual violence, parents, students and other parts of society were able to protect themselves from the potential mentioned case.
\end{abstract}

Keywords: Sexual Violence and Teen Girl.

\section{ABSTRAK}

Salah satu bentuk tindak kekerasan yang sering dialami oleh anak dan kelompok remaja khususnya perempuan adalah tindak kekerasan seksual atau pelecehan seksual. Berbagai bentuk dan modus pelaku tindakan kekerasan secara seksual ini mayoritas dilakukan oleh kelompok orang dewasa dan bahkan anggota keluarga terdekat. Para pelaku pendidik yang notabene menjadi panutan para anak didiknya justru melakukan tindakan yang diluar etika, nilai dan norma. Menghadapi permasalahan ini, maka sekiranya dibutuhkan wawasan dan sebuah strategi guna mencegah terjadinya tindak kekerasan seksual yang menimpa kalangan usia anak dan remaja khususnya perempuan. Upaya yang dapatdilakukan adalah mengedukasi pendidikanseksual pada beberapa pihak terkait dan pada anak dan remaja perempuan agar mampu mengenali jenis atau bentuk dari kekerasan seksual. Bentuk edukasi yang dilakukan menggunakan metide atau teknik sosialisasi dan penyuluhan. Sosialisasi dilakukan dengan membagikan atau kampanya dengan menyebarkan pamflet dan stiker kepada kelompok-kelompok remaja dan warga masyarakat umum. Instansi sekolah tingkat SLTP dan SLTA menjadi bagian sasarannya. Metode penyuluhan dilaksanakan dengan mitra SMAN 1 Merawang. Kegiatan ini menghadirkan narasumber dari latar belakang kesehatan dan psikologi. Harapannya dengan adanya wawasan tentang ragam jenis dan bentuk tindakan kekerasan, para orang tua, masyarakat bahkan anak dan remaja perempuan dapat membentengi diri dari ancaman tindak kekerasan yang ada disekitarnya.

Kata Kunci: Sexual Violence dan Remaja Perempuan 


\section{PENDAHULUAN}

Masyarakat sebagai sebuah sistem sosial yang besar sudah pasti terdiri atas berbagai unsur yang membangunnya. Sebagai sebuah kumpulan individu dalam jumlah yang besar, keberagaman dalam tindak perilaku tentunya akan muncul. Nilai-nilai yang terkandung di dalamnya tidaklah senantiasa ditaati oleh para individu sebagai anggota yang berada di dalamnya. Padaproses-proses sosial yang muncul tentunya ada yang mengarah pada yang sifatnya assosiasif dan disosiasif (Rendy,2018 ; Sujadmi, 2017).

Perilaku yang cenderung bersifat dissosiasif adalah perilaku yang senantiasa mengarah pada penyimpangan terhadap nilai dan norma sehingga memunculkan keresahan sosial. Salah satunya perilaku tentang seksualitas. Seksualitas merupakan aspek-aspek terhadap kehidupan manusia terkait faktor biologis, fisiologis, sosial, budaya dan politik terkait seks dan aktifitas seksual yang mempengaruhi masyarakat (Sussman, 2008 ;De Buvoir, 2016).

Membahas mengenai seksulitas bukanlah hal yang sederhana. Seksualitas menjadi sebuah persoalan yang semakin kompleks dari waktu ke waktu ketika terdapat kebudayaan lain yang dinilai lebih tinggi sebagai pembandingnya. Persoalan seksualitas seakan-akan menjadi hal yang bukan lagi tabu.

Kompleksitas persoalan wacana sekualitas kian menjadi kala beberapa waktu terakhir ini terus muncul di publik. Salah satunya persoalan tindak pelecehan dan kekerasan seksual yang terjadi pada kalangan usia anak dan remaja. Anak dan remaja senantiasa menjadi obyek sasaran tindak pelecehan dan kekerasan seksual karena dinilai sebagai pihak yang lemah (Soekanto, 2009). Kekerasan atau pelecehan seksual merupakan perilaku pendekatan terkait dengan seks yang tidak diinginkan, termasuk permintaan untuk melakukan seks, dan perilaku lainnya yang baik secara verbal maupun fisik merujuk pada seks.
Kasus pelecehan seksual terhadap anak dan remaja ini kian merebak di publik. Jumlah baik korban maupun pelaku dari tahun ke tahun terus mengalami peningkatan.Jumlahangka

peningkatannyapun cukup luarbiasa, tahun 2014-2016 angka nasional mencapai angka $100 \%$ (data KPAI, 2017). Hal ini menunjukkan bahwa perlu adanya perhatian khusus guna mencegah tindak kekerasan dan melindungi hak-hak anak dan remaja.

Pada Provinsi Kepulauan Bangka Belitung kasus pelecehan seksual juga terjadi di berbagai kalangan. Hal yang sangat tragis beberapa waktu terakhir tindak pelecehan seksual terjadi pada institusi pendidikan atau sekolah.

Kasus ini jika tidak segera ditangani tentunya akan memberi dampak yang luas dan besar bagi kehidupan masyarakat khususnya pada anak dan remaja. Banyak dampak yang dimunculkan dari tindak pelecehan atau kekerasan seksual yang dialami oleh anak dan remaja. Efek dari kekerasn seksual ini berkenaan langsung terhadap kondisi kehidupan anak dan remaja baik selama maupun setelah kontak seksual dan dapat berlangsung lama setelah kejadian kekerasan seksual berhenti.

Dengan demikian, sekiranya sangatlah diperlukan adanya pendidikan seks sejak dini. Kegiatan ini bertujuan guna memberikan wawasan dan pengetahuan pada orang tua, anak dan remaja tentang urgensi membentengi diri sejak dini dari tindakan atau ancaman kekerasan seksual.

Pada kegiatan ini melibatkan beberapa lembaga sebagai itra kegiatan. Lembaga yang dinilai dapat menjadi mitra untuk dilibatkan dan diajak bekerjasama dalam kegiatan pengabdian masyarakat, yaitu:

1. Pusat Studi Perempuan

Universitas Bangka Belitung sebagai kampus yang memiliki visi untuk menjadi kampus riset, dilengkapi dengan beberapa lembaga yang menunjang dibidang riset dan pengabdian kepada masyarakat. Lembaga-lembaga ini mendorong 
kampus untuk melaksanakan Tri Dharma Perguruan Tinggi. Pusat studi merupakan lembaga yang berada dibawah LPPM-UBB yang mengkaji persoalan anak dan perempuan. Pusat studi ini didirikan guna merespon permintaan dari para sivitas akademika dan masyarakat umum guna melakukan kajian-kajian ilmiah tentang anak, perempuan, dan pembangunan.

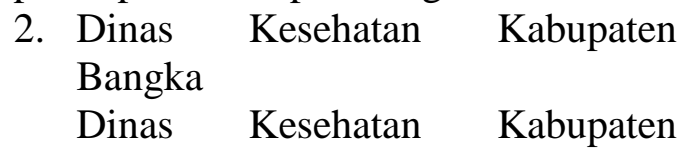
Bangka merupakan unsur pelaksanan Pemerintah Daerah Kabupaten yang berada dibawah dan bertanggung jawab kepada Bupati melalui Sekretaris Daerah. Dinas Kesehatan ini memiliki tugs di bidang kesehatan. Dins Kesehatan memberikan pelayan kepada masyarakat. Beberapa fungsi dari Dinas Kesehatan diantaranya fungsi penyelennggaraan umum dalam bidang medis. Lebih lnjut berfugsi sebagai pelaksana dan pembina tugas dalam bidang pelayanan, pencegahan penyakit dan ruujukan, usaha kesehatan serta sumber daya kesehatan di lingkup kabupaten.

3. Himpunan Mahasiswa Jurusan Sosiologi

Merupakan kelompok mahasiswa yang tergabung dalm wadah organisasi. Organisasi kemahasiswaan ini sebagai tempat bagi mhasiswa khususnya di jurusan dalam mengasah dan menambah keilmuan yag bersifat non akademik dan memperdalam kemampuan akademik dengan langsung praktik atau terjun ke masyarakat. Himpunan Mahasiswa Jurusan Sosiologi ini berdiri sejak tahun 2006 seiring dengan adanya Jurusan Sosiologi di Universitas Bangka Belitung yang pada waktu itu masih berstatus dibawah sebuah yayasan.

4. SMAN 1 MerawangKabupaten Bangka
Sekolah Menengah Atas (SMA) adalah jenjang pendidikan menengah pada pendidikan formal di Indonesia setelah lulus Sekolah Menengah Pertama (atau sederajat). SMA diselenggarakan oleh pemerintah maupun swasta. Sejak diberlakukannya otonomi daerah pada tahun 2001, pengelolaan SMA negeri di Indonesia yang sebelumnya berada di bawah Departemen Pendidikan Nasional, kini menjadi tanggung jawab pemerintah daerah Kabupaten/Kota.Sedangkan Departemen Pendidikan Nasional hanya berperan sebagai regulator dalam bidang standar nasional pendidikan. Secara struktural, SMA negeri merupakan unit pelaksana teknis dinas pendidikan Kabupaten/Kota. Salah satu Sekolah Menengah Atas yang ada di Kabupaten Bangka adalah Sekolah Menengah Atas (SMA) Negeri 1 Merawang. SMA Negeri 1 Merawang merupakan pendidikan formal yang ditempuh dalam waktu 3 tahun, mulai dari kelas 10 sampai kelas 12.

Kelompok sasaran mnjadi hal yang penting dalam pelaksanaan program kegiatan ini. Mengidentifikasi kelompok sasaran potensial, kebutuhan spesifiknya, serta potensi kekuatan kelompok sasaran dan sumber-sumber yang dapat dimanfaatkan untuk kepentingan kelompok sasaran.Kelompok sasaran yang menjadi target dalam pelaksanaan kegiatan pengabdian masyarakat ini adalah para siswa yang masuk kategori usia anak dan remaja di sekolahsekolah (SMP/SMA) Kabupaten Bangka serta pihak-pihak lain yang terkait yang mempunyai kemauan maupun kemampuan untuk mendukung pemerintah dalam upaya pencegahan masalah tindak kekerasan seksual yang terjadi pada usia anak dan remaja. 


\section{METODE PENELITIAN}

\section{A. Waktu dan Tempat Kegiatan}

Kegiatan pengabdian Iptek bagi Msyarakat (IbM) ini mengambil rentang waktu dari bulan Mei sampai Oktober tahun 2018. Kurang lebih dalam rentang waktu 6 (enam) bulan ini, keseluruhan tahapan kegiatan mulai dari proses persiapan hingga pelaporan dilaksanakan. Kegiatan pengabdian IbM ini mengambil lokasi secara umum di wilayh Kabupaten Bangka. Secara spesifik puncak kegiatan IbM ini dilaksanakan di SMAN 1 Merawang Kabupaten Bangka.

\section{B. Tahapan dan Metode Pelaksanaan}

Tahapan pelaksanaan kegiatan Ipteks Bagi Masyarakat yang dilaksanakan di lingkup wilayah Kabupaten Bangka khususnnya di SMAN 1 Merawang ini telah melalui beberapa tahapan. Tahapan kegiatan yang telah dilaksankan adalah:

\section{Tabel}

Tahapan Kegiatan

\begin{tabular}{|c|c|}
\hline Tahapan & Keterangan \\
\hline Persiapan & $\begin{array}{ll}\text { a. Identifikasi } \\
\text { permasalahan } \\
\text { b. Pengumpulan } \\
\text { informasi dan dokumen } \\
\text { sebagai data sekunder } \\
\text { c. Identifikasi mitra } \\
\text { d. Penyusunan proposal } \\
\text { e. Tanda tangan kontrak } \\
\text { f. Revisi proposal }\end{array}$ \\
\hline Pelaksanaan & $\begin{aligned} & \text { a. } \text { Koordinasi dengan } \\
& \text { mitra pelaksana } \\
& \text { b. }\end{aligned}$ \\
\hline
\end{tabular}

\begin{tabular}{llr}
\hline & \multicolumn{2}{l}{$\begin{array}{l}\text { masyarakat, anak, dan } \\
\text { remaja) }\end{array}$} \\
& e. & PENYULUHAN \\
& (bermitra dengan \\
& SMAN 1 Merawang \\
& sebagai & lokasi \\
& pelaksanaan & \\
& penyuluhan) & \\
& a. & Pelaporan \\
Akhir & b. Monitoring \\
& c. Evaluasi
\end{tabular}

Sumber: HasilPengolahan Data

OlehPenelitiTahun 2018.

C. Pemecahan Solusi yang Ditawarkan

1. Metode Pelaksanaan

Kegiatan IbM kali ini menggunakan metode sosialisasi terarah atau kampanye yang langsung menyasar obyek di lapangan. Metode ini dilakukan atas dasar pertimbangan ingin langsung menjemput bola dan menghilangkan kesan formal atau kaku. Dengan cara yang lebih santai, ringan tapi langsug menyasar pada obyek. Obyek yang disasar dalam kegiatan ini adalah remaja, mka metode yang digunakan pun diarahkan pada cara yang dapat diterima dan tidak menjenuhkan

Atas dasar pertimbangan tersebut, maka metode sosialisasi yang dipilih dalam IbM kali ini adalah dengan menyebarkan atau membagikan stiker dan pamflet kepada para anak dan remaja serta orang tua/warga masyarakat. Selain itu juga dilakukan metode dengan kegiatan penyuluhan yang menghadirkan narasumber yang dapat memberi pemahaman dan motivasi baik secara biologis/kesehatan medis dan secara psikologis /psikolog/ motivator

2. Program Kegiatan

a. Identifikasi.

b. Pemetaan danperumusan.

c. Perencanaan.

d. Sosialisasi dengan media pamflet dan stiker. 


\author{
e. Pelaksanaan \\ penyuluhan \\ seksualitas.
}

f. Pelaporan kemajuan.

g. Monitoring dan evaluasi.

h. Pelaporan akhir.

3. Partisipasi Mitra dalam Pelaksanaan Program

Pada kegiatan IbM yang dilaksanakan kali ini, tlah melibatkan beberapa pihak yang dinilai cukup relevan dan berkompeten untuk bemitra. Pihak mitra yang dilibatkan dalam kegiatan $\mathrm{IbM}$ ini adalah Pusat Studi Perempuan (PSP) UBB, Himpunan Mahasiswa Jurusan Sosiologi (HMJ SOS) FISIP UBB, dan SMAN 1 Merawang Bangka.

Partisipasi dalam hal pelaksanaan sosialisasi dengan menyebarkan pamflet dan stker ke beberapa titik lokasi dii wilayanh kabupaten Merawang melibatkan mahasiswa HIMA Sosiologi FISIP UBB. Hal ini merupakan sarana pelatihan mahasiswa untuk meningkatkan kepekaan dan kemampuan dalam berkomunikasi dengan masyarakat di luar kampus. PSP UBB sebagai mitra juga mengambil peran yang pentiing, dimana dengan relasinya maka dapat dihadirkan narasumber yang cukup berkompeten dalam memberikan materi penyuluhan.

Terakhir yang tidak kalah pentingnya adalah SMAN 1 Merawag sebagai mitra. Mitra ini cukup penting mengingat memberikan ijin penyediaan tempat dan obyek sasaran untuk melakukan penyuluhan. Dengan demikian kegiatan ini dapat berjalan sesuai dengan yang direncanakan.

\section{III.HASIL PENELITIAN DAN PEMBAHASAN}

Program kegiatan IbM ini dilatar belakangi oleh maraknya atau tingginya angka pernikahan diusia anak yang terjadi di wilayah Provinsi Kepulauan Bangka Belitung. Selain itu dalam beberapa kurun waktu terakhir, semakin bertambahkan kasus kekerasan seksual yang dialami oleh anak dan remaja. Pelaku tindak kekerasan ini pun merupakan orang terdekat yaitu pihak keluarga dan dari lingkungan sekolah.

Berangkat dari hal ini, maka dinilai perlu untuk dilakukan penyuluhan dan sosialisasi kepada warga masyarakat khususnya generasi remaja akan pengetahuan seputar kesehatan reproduksi yang dibingkai dalam pendidikan seks usia dini. Selama masyarakat selalu menggaggap bahwasanya persoalan seks adalah hal yang tabu untuk dibahas di publik terutama pada anak kecil. Anggapan ini yang menjadikan tidak adanya counter knowledge dari pihak orang tua terhadap anak. Orang tua menilai bahwa hal-hal yang berkenaan dengan seksualitas adalah konsumsi orang dewasa, sehingga anak akan cenderung mencari tahu dari media.

Salah satu upaya yang dilakukan untuk melakukan pendidikan seks di usia dini, yaitu:

1. Sosialisasi

Sosialisasi dilakukan dengan menyebarkan pamflet dan stiker yang berisi himbauan untuk menolak tindak kekerasan. Materi yang disampaikan berupa pentingnya membentengi diri dan mengenali organ tubuh diri sendiri. Lebih lanjut tentang pemahaman batasa-batasan tindakan atau perilaku yang dikatakan sebagai tindak kekerasan seksual.

Pada tahapan ini, fokus sasarannya yakni pada anak-anak usia sekolah dan orang tua. Langkah ini diambil dengan pertimbangan mencari media yang relatif ringan dan mudah dipahami (Bungin, 2006). Bahasa yang digunakanpun bahasa yang bersifat preventif dan himbauan untuk samasama mencegah dan menghindari adanya kekerasan seksual pada anak.

Pelaksanaan metode sosialisasi dengan penyebaran pamflet ini dilakukan dalam kurun waktu kurang lebih tiga bulan, yang tentunya tidak 
secara terus-menerus. Selama kurun waktu tiga bulan tersebut diambil waktu-waktu tertentu dengan menyesuaikan atau melihat moment yang dinilai pas. Bebebrapa momentum yang diambil adalah dengan mengunjungi sekolah-sekolah pada saat siswa-siswinya melakukan kegiatan ekstrakurikurer di hari Jum'at dan Sabtu. Teknik lain yakni dengan menyambangi Posyandu dimana terdapat anak-anak dan orangtua yang hadir.

Dengan menyasar langsung pada anak-anak atau remaja usia sekolah dan orangtua, harapannya dapat memberikan atau membuka wawasan dan kesadaran akan pentingkan perlindungan diri pada anak dan kontrol orangtua terhadap anakanaknya dalam pergaulan sehari-hari.

2. Penyuluhan

Untuk meningkatkan pemahaman akan pentingnya menjaga diri, mengenali organ tubuh diri, dan kesehatan reproduksi, dilibatkan narasumber yang memiliki latar belakang kesehatan dan psikologi.Harapannya dari dua bidang kompetensi ini, mampu memberikan pemahaman, penyadaran, dan motivasi bagi para generasi akan bahayanya seks bebas, kekerasan seksual, serta arti penting dari belajar dan meraih prestasi. Rangkaian kegiatan ini senantiasa melibatan mitra.Harapannya dari kegiatan ini dapat membangun relasi yang mampu bekerjasama guna mencegah kekerasan seksual pada remaja.

Kegiatan penyuluhan yang dilakukan pada kesempatan ini dengan melibatkan mitra utama yang menjadi sasaran adalah salah satu sekolah yang berada di Kabupaten Bangka, yakni SMA Negeri 1 Merawang. Sebanyak kurang lebih 60an siswa terlibat dalam agenda penyuluhan ini.

Narasumber dalam kegiatan penyuluhan ini melibatkan pihak yang kompeten dibidang psikologis dan medis atau kesehatan reproduksi. Melalui dua narsumber ini disampaikan materi yang berkenaan dengan motivasi dan perilaku hidup sehat serta wawasan mengenai alat reproduksi khususnya remaja putri.

\section{IV.KESIMPULAN}

Kegiatan pengabdian kepada masyarakat ini memfokuskan pada anak dan remaja usia sekolah sebagai sasarannya. Usia sekolah yang dimmaksud disini adalah tingkat SLTP dan SLTA/sederajat. Anak usia sekolah disini lebih kepada yang berada di lingkung wilayah Merawang Kabupaten Bangka. Hal ini mengingat banyaknya instansi pendidikan di wilayah ini dan merupakan wilayah yang berdekatan dengan kota, sehingga remajanya relatif rentan terhadap pergaulan di masa-masa transisi atau peralihan desa menuju kota.

Berdasarkan hasil observasi di lokasi, terdapat beberapa hal yang perlu menjadi perhatian bersama. Terdapat beberapa permasalahan yang dihadapi baik anak dan remaja maupuun warga masyarakat selaku orang tua bahkan guru-guru di sekolah. Permasalahn yang ditemui diantaranya sebagai berikut:

1. Pada setiap tahunnya selalu terdapat siswa yang putus sekolah dengan alasan menikah;

2. Terdapat tindak kekerasan seksual yang dialami oleh siswa dan pelakunya adalah guru;

3. Orientasi siswa putri cenderung berkeinginan untuk menikah ketika lulus SLTP ataupun SLTA ketika sudah ada yang melamar;

4. Guru dan orang tua serta masyarakat sebagian masih menilai bahwa seksualitas adalah urusan orang dewasa dan menjadi hal yang tabu untuk dibahas;

5. Relatif minimnya pengetahuan anak, remaja, orang tua, dan warga masyarakat secara umum mengenai 
makna, maksud, dan tujuan dari pendidikan seksualitas sejak dini.

\section{DAFTAR PUSTAKA}

[1] Bungin, Burhan. (2006). Sosiologi Komunikasi.Kencana, Jakarta.

[2] De Beauvoir, Simone. (2016).Second Sex. Pustaka Promethea, Jakarta.

[3] Rendy \& Sujadmi. (2018). Meretas Mitos Menggali Makna Pernikahan Usia Anak.

[4] Soekanto, Soerjono,. (2009). Sosiologi Keluarga:Tentang Ikhwal Keluarga, Remaja dan Anak. Rinneka Cipta, Jakarta.

[5] Sujadmi, Rendy \& Sandy P. (2017). Analisis Pengaruh Faktor Ekonomi Terhadap Tingkat Perceraian di Kabupaten Belitung. BKKBN Provinsi Kepulauan Bangka Belitung.

[6] Susman, Steve \& Ames, Susan L. (2008).Drug Abuses Concept, Prevention, and Cessation. Cambridge University Press, Cambridge. 